\title{
The Changing Perspectives of Three Muslim Men on the Question of Saint Worship over a Io-Year Period in Gujarat, Western India ${ }^{1}$
}

\author{
EDWARD SIMPSON
}

\author{
School of Oriental \& African Studies, University of London, Thornhaugh \\ Street, Russell Square, London $W C_{I} H$ oXG, UK
}

\begin{abstract}
In many religious traditions, those who mediate relations between men and gods are often the focus of controversy and moral ambiguity. The ethnography in this paper outlines a number of perspectives on the role of such intermediaries (here 'saints') in Muslim society in western India. In the South Asian literature, historians have provided a thorough treatment of the doctrinal history and content of these debates. However, very little attention has been paid to how living individuals interpret and rehearse these debates in practice. The examination of the changing perspectives of three Muslim men on the question of saint worship over a 10 year period reveals the following. First, an individual's relationship with 'saints' is often determined primarily by social context rather than simply by doctrinal allegiance or the compulsions of particular 'beliefs'. Second, discourses of religious reform are also powerful social objects that can be used as political instruments for purposes other than simply refining the religious practices of a community. Finally, many commonplace assumptions in the literaturenotably on the nature of belief and the significance of doctrinal divisions among Muslims-do not withstand ethnographic scrutiny.
\end{abstract}

\section{Introduction}

In this paper I discuss how three Muslim men hold to be true apparently contradictory ideas about the legitimacy of saints. The principal argument is that much of the sociology of religion, at least as often expressed in contemporary anthropology, relies on

1 The fieldwork on which this paper is based was funded by the Economic and Social Research Council (ROo429634237). I am grateful to Caroline and Filippo Osella, Carrie Hietmeyer, Jason Sumich and Sylvia Vatuk for commenting in constructive ways on this material. The names used in the text are pseudonyms. 
somewhat static and instrumental notions of belief and knowledge. I illustrate this and demonstrate the consequences for the more general understanding of popular Islam and reformism in South Asia.

The kind of simplifying drudge I have in mind is most extremely characterized by surprisingly common statements such as 'Muslims believe $\mathrm{X}$ and Y', the error of which hardly need to be demonstrated to readers of this journal. However, there are other levels at which this tendency operates. It requires cultivated personal or professional interests in order to question statements such as, 'The Barelvis hold that spiritual intermediaries are a vital part of the society of Islam'. Such statements should beg the following kinds of questions: is this group of Muslims (associated with the teaching of Ahmed Rida Khan and Hanafi jurisprudence) formed solely by the uniformity of belief among its members? Do all spiritual intermediaries hold Barelvis in equal regard with other Muslims? Are all intermediaries held in equal regard by the Barelvis? Who says so? How do they know? What does it mean to believe or hold that something is true? While it is beyond my scope here to provide a confident answer to the final question, my data illustrates some of the limitations of discussing religious belief-and thus also ideas of reform-in terms of truth and certainty at the level of the individual and hence, by extension, at the level of the group.

The paper is broadly divided into three parts. The first section places my material within the existing body of literature on Islamic reform in South Asia, introduces the ethnographic context and outlines general debates about the legitimacy of saint worship. The second section is ethnographic, and describes the changing perspectives of three men over a 10-year period in Gujarat, western India, on the question of saint worship. The third section broadens perspective, to tie the ethnography into shifts in religious politics in western India.

\section{Islam and Modernity in South Asia}

Many accounts of Muslim societies have focused on the division between those who venerate living or dead saints as intermediaries between themselves and Allah, and those who condemn such beliefs and practices. For some scholars, clearly influenced to a degree by their own religious practices and anthropological beliefs, this division has been dealt with as matter of religious philosophy and as a fundamental contradiction at the core of Islam (notably Gellner 1969, Gibb 1972). These scholars are not entirely wrong to emphasize this division, 
because it is also a rhetorical device often used by Muslims themselves, and one that has historically driven many reformist movements (see Eickelman 1981, 1982). Scholars and Muslims alike have often busied themselves with rhetoric, seeming to hold that matters of belief and practice will follow unquestioningly behind the words of reform.

Drawing on ethnography from the southern coastal belt of Kachchh District in the far west of Gujarat, I suggest that the separation of 'saint worshippers' (often equated to syncretism and the irrationality and superstition of mythos and, inaccurately, likened to Catholicism, i.e. those who 'believe' in saints) from 'non-saint worshippers' (often equated to the rationality of logos and 'reform', and thus inaccurately likened to Protestantism, i.e. those who 'do not believe' in saints) is a sociological falsehood which has become entrenched in the anthropology of Muslim societies, or, to be more careful in my claims, this division is something I am unable to extract consistently from my own ethnography.

As a way into discussion, I make two further claims: the first relates to the predominance of historical knowledge of particular types in the literature and the second to the enduring legacy of a kind of thought, most accurately described as 'functionalist', in the anthropology of Muslim societies.

Much of the best work on Islam in India has been written by historians, notably those working on the pre-colonial (Eaton 1978, 2001) and colonial periods (Zaman 1999a, 1999b; Robinson 2001, 2003; Metcalf 2004, 2005; Reetz 2006). This work has focused primarily on the emergence of 'reformist' movements in the northern part of the country during the nineteenth century. Hence, there is something of a lopsidedness to our knowledge: we know more, and more thoroughly, about the historical development of reform movements and their relationship to colonial thought and practice than we do about the lives of Muslims in either colonial or contemporary society. Thus, when one turns to the background to Islam in South Asia, the key texts tend to focus on schools of thought, key figures, and the delineation and relationship of these schools to the competitive world of preindependence politics. Such works have a certain epistemological character (the consequences of which I turn to below), and generally build upon one another. This observation is not simple disciplinary sniping, but has tangible effects on the contemporary production of knowledge about Muslims and modernity in South Asia.

A recent book by the sociologist Rowena Robinson (2005), on Muslims affected by violence in Mumbai and Gujarat, provides a good 
example of the consequences of this lopsidedness for the study of contemporary India. Robinson's text is rich with data from interviews, but the details of doctrinal differences among Muslims are trotted out in a much more formal-if not to say formulaic — style in explanatory footnotes. Significantly, I strongly suspect this-is because Robinson had to turn to historians' work for the details presented in these footnotes and because most of her interviewees would not, nor could they even if pressed, describe differences between Muslims in these terms. We learn, for example: 'Deoband teachings manifest a distrust of other cultures and seek to purge Islam of Western and modernist influences and to establish the Quran and the Hadith ('sayings' of the Prophet) as the sole source of tradition' (2005: 189, note 7). In contrast, 'Unlike Deobandis, Barelvis believe in the powers of the Prophet and the saints' and '... believe in the intercession between humans and the divine through a chain of holy pirs [saints] ultimately reaching the Prophet (2005: 190, note 11). We learn about the 'Sufi influences' that inhere within the religious practices of Indian Muslims and the growth of reformist movements such as the Ahl-e-Hadith, Jamat-e-Islami and Jamat-e-Ulema-e-Hind, movements opposing the worship of saints often described by the generic terms 'Wahhabi' or 'Salafi'.

In this fashion, work on Indian Muslims stresses the significance of divisions, notably by devotion or aversion to saints. ${ }^{2}$ The literature, of which Robinson's text is but an example, also stresses the importance of reform as the principle idiom of both religious practice and theological division. ${ }^{3}$ The temptation is, therefore, to see institutionalized forms of Islam-characterized by a place and date of origin, a seminary, perhaps a series of well-catalogued (and thus readily accessible) publications, and an uncontested set of beliefs and practices - as reflecting popular understandings of Islam in India. To my mind, however, there are simply too many improbable assumptions involved in this picture of Islam on the sub-continent for it to stand.

${ }^{2}$ The major works on Muslims in Gujarat bring similar categorizing principles to the topic. The gazetteers of the nineteenth century built upon the colonial practices of census and classification and catalogue castes and the relationships between caste and sect; see, for example, see the 1899 publication Gazetteer of the Bombay Presidency. Vol. IX. Part II. Gujarat Population: Musalmans and Parsis. Twentieth century publications by social scientists (Engineer 1989) and historians (Misra 1964) have been written along similar lines.

${ }^{3}$ In a sense, it is perfectly correct to stress purges of practice and the struggle for change because this is the nature of jihad; the faithful are necessarily reformers in a generic sense, but this is not a point to emerge from the literature I am discussing. 
The differences between schools of thought are much more difficultif not impossible-to demarcate consistently at the level of actual practices and actual people-not everywhere always, but in many places often. Moreover, people's knowledge of different schools varies considerably, while relationships between rival sects may have as much to do with political or economic factors as they do with debates about authenticity or legitimacy.

Of course, Muslims I know recognize many divisions among themselves and it is indeed true that particular mosques are often associated with particular doctrines. I also know families in which fathers and sons attend different mosques for such doctrinal reasons (or so they say). While I am not disputing the presence of differences in doctrine, I am suggesting that they should be placed in their proper relation to other social cleavages. None of my friends and informants in Gujarat would be able to offer the kind of bird's-eye and historicized account of religious division that Robinson's footnotes, echoing historians, provide. Indeed, why should they be expected to?

The general overview is, I have suggested, something that anthropologists object to because it does not reflect the reality of anyone other than the historian or the footnoting sociologist. In this instance, the overview is worth extra critical scrutiny because in dayto-day life in Gujarat the visibility of divisions between sects is very strongly obscured by contours of friendship, animosity, ethnicity, class, caste and other kinds of politics. The persistence of the idea of what I am calling 'the overview' (but which could equally be thought of, less flatteringly, as a catalogue), rooted as it is in colonial and historical practice, seems yet another example of the way in which Muslims are reduced to religious rather than sociological terms. In what follows, and to escape the tension between the dictates of authoritative text and actual practice, ${ }^{4}$ I take as a starting point Muslim social thought 'as it is not as it should be', to use Francis Robinson's (1983: 155) well-turned phrase. This means using the terms of reference of my friends and informants as the analytical starting point.

This brings me to my second claim about the epistemology of the anthropology of Muslims and the legacy of functionalism. The binary of 'saint worshippers' and 'non-saint worshippers' (or for that matter generic Muslims and generic Muslim reformers) stems, in part, from the enduring legacy of anthropological regimes which separated 'religion' from discussions of family and politics-amongst

${ }^{4}$ See Das (1984), Lindholm (1986) and Robinson (1983) for some lively exchange on this topic. 
other things. This trend turned simple questions of everyday moral reasoning into theological debates, which they were properly not at all. Furthermore, the models of logic and process on which much anthropological theory is based have tended to shy away from confronting contradictions (such as the co-existence of the immanent and the transcendental), preferring instead neat and cohesive systems and structures over mess and ambiguity.

The twin ideas that people are routinely engaged in activities other than religion and that religious ideas impinge on mundane domains are truisms in other areas of anthropology and sociology. The anthropology of Muslims has, however, been slower to embrace the theoretical advances of post-colonial, post-Oriental and, indeed, poststructuralist thinking. A shift in emphasis is necessary: away from the study of Muslims as people necessarily shaped by religious doctrines and towards a more properly anthropological concern with Muslims as people who are engaged in all manner of other social and worldly processes aside from the 'religious'. There are of course important exceptions; Rosen (1984, see also Asad 1986) eloquently shows how the social realities of Moroccan Muslims are formed from shifting networks of negotiable obligations and relationships rather than fixed abstract precepts. Similarly, Eickelman and Piscatori's (1996) discussion of the language of Muslim politics illustrates how terms are opened up for debate and contestation. More recently, scholars such as Verkaaik (2004), Marsden (2005) and Soares (2005) have stressed some of the ambiguities and conflicts in being Muslim and the significance of scepticism, humour, irreverence and unfinished conversations.

I draw on what might be thought of this recent anti-functionalist stance (individual authors frame their own 'anti-' differently) to assume that ambiguities and inconsistencies-rather than fixed certainties given by texts and unproblematic beliefs-are as central to the social life of Muslims as non-Muslims. I also take it as given that individuals have context-bound selves that shift in form and intention over time (as in Holland and Leander 2004). I immediately caution against facile assumptions here: the world I am attempting to convey is not an unchained whirligig of limitless and unbounded humanity, but one in which uncertain individuals are, by and large, also bound in uneasy relationships to the structures of their society and the history of Islam.

Anthony Giddens (1979: 161) suggests that human beings everywhere exist in contradictory relation to nature. Contradiction arises because humans are in and of nature, but they are also set apart 
from it because they have a 'second nature', not reducible to physical objects. This contradiction, Giddens explains: '... has its universal expression in the finitude of Dasein as the negation of the apparent infinity of time-space in which each human life makes its fleeting appearance' (1979: 161). ${ }^{5}$ This is not simply to say that nature is negated by the 'second nature' of humans (for Giddens, it appears to be), but that this fact gives humans a 'contradictory unity' that in turn makes them further distinct from nature. The relation between Dasein and the continuity of being is always mediated by society, and thus the existential contradiction of human existence is reflected in structural contradictions in society.

There is no space here to grapple with the vast literature on the relationship between individual and collective forms of representation or the self in relation to society. I wish, quite simply, to follow Katherine Ewing's (1997) useful investigation of modernity, psychoanalysis and Islam in Pakistan. Ewing takes Lacan to Lahore to explore the ways debates around sainthood are used to question and anchor individual conflicts, uncertainties and the quest for recognition. She demonstrates, echoing Giddens, how individual fantasies of identity are caught simultaneously in seemingly stable webs of plenitude and public talk on one hand and constantly threatened by the transience of life and the immanence of death on the other. Thus, Ewing is able to expose some of the deep sediment of meaning which forms invisible/intangible parts of the relations between saints and their followers and detractors. We could infer from her work that to their followers, saints embody the negation of time through both genealogy and ritual proximity to the infinite.

I now introduce the three men of my title and explore the nature of individual uncertainties and how these manifest in broader social trends.

\section{The Ethnographic Context}

One day in 1999, Rafiq and I had made a short journey from his shipyard on the east bank of an estuarine creek to the local town on the west to obtain customs clearance for his vessel. After we left the customs office, we stood on the docks to look through the tangle of shipyards and onto the river. Rafiq initiated conversation with some

\footnotetext{
5 The German term Dasein is from Heidegger's (1962) examination of what it means 'to be' and translates roughly as 'being-there', 'life-world' and 'existence'.
} 
men rigging a vessel in the mud before us. As we chatted, along came a man dressed from head to toe in green silk. He smelt strongly of perfumed oil and carried with him a number of peacock feathers and a bundle of grubby charms. He looked like a rogue but his words were considered and his tone contemplative. He said he was a Saiyed from Rajasthan who was making a tour of the holy places of Gujarat. He flattered Rafiq with kind words, waved the feathers in the general direction of his head and asked for alms. Rafiq had bent slightly to receive the blessing, and reached inside his immaculate white robes to pass the man ten rupees. The man gratefully took the note but did not leave as Rafiq had clearly expected him to. The stranger attempted to prolong the exchange, perhaps believing he had stumbled across a potential patron. To everyone's surprise, especially that of the Saiyed, Rafiq told him in no uncertain terms to get lost. The man was clearly shocked and, as he started to regain composure, he informed Rafiq that this was no way to treat an elder, a man of religion and a traveller in a strange land. Rafiq replied by saying that waving feathers around was no sign of religion, that the man was certainly old but not his superior and if the man was hungry he should go to eat in a lodge and pay for his food like everyone else. The overt confrontation in this exchange was out of the ordinary and provoked some audible giggles from among the men on the ship. Their reaction spurred Rafiq on: 'I have been on haj. My family has built mosques and given generously to orphanages. What are your qualifications?' There was a moment of silence before the man replied: 'Well Haji, I may be a poor man but I at least know how to behave'. He turned his back and walked away.

Rafiq had publicly lied-he had not been on haj-but the lie was plausible and served its purpose. As we made the journey back to his village, Rafiq moaned that he was sick of self-appointed authorities asking him for money in the name of Islam. I knew that already, because he talked about it all the time, but I simply could not understand why he had taken the man's blessing and paid for the service and then insulted the fellow. I asked him, and he retorted: 'that fellow on the docks, who was he? I have no idea! You have no idea! He may have been the son of an oil presser from Uttar Pradesh who has moved over here and started to claim he is a bawa [saint] but he might not have been. You have to be careful. These people have powers, whether we like it or not. I took his blessing before insulting him, just to be on the safe side'.

Insulting those you trust to confer blessings is clearly at odds with much conventional wisdom about the morality of exchange and reciprocity associated with popular Islam in South Asia. For Rafiq, it 
was as if receiving the blessing closed the way (perhaps optimistically) for any malicious intent the man in green might have subsequently wished towards his younger critic. Over the years, I have witnessed many similar forms of exchange, but this one particularly stuck in my mind because Rafiq had told me vehemently on many occasions (both before and after this encounter) that saints and their powers had no place in 'real Islam' (his words).

Do these apparently contradictory forms of behaviour mean he is slovenly in his thinking or simply driven by the opportunities of the moment? While I would not completely discount either of these options, I also suspect more compelling explanations, to which I will return later. First, however, I outline the role of saints in western India and some of the reasons why they are the targets of reformers in order to contextualize why and how it is important that the three men discussed have changing perspectives.

\section{Saints in Western India}

Notwithstanding the Christian connotations of the word 'saint', I use it here to refer to a group of living Saiyeds who manipulate the grace and potency of their genealogy to intervene in lives of their followers, with miracles, advice, boons, sacred amulets and so forth. In Gujarati, such people are known as pir. The role and social position of such figures are commonly linked to Sufi traditions (Mills 1998), and while there is much historical evidence to affirm such connections, this is not something my Sunni informants stress. In Kachchh, as elsewhere, there is considerable variation in the qualifications, methods and reputation of local saints. Some have small informal followings and no fixed place of business; others live and practice within elaborate shrines, which may contain the graves of hundreds of dead ancestors, and where interaction between saint and devotee is determined by formal codes. Saints may be called upon to appease 'non-Muslim' deities, adjust problems of human or agricultural fertility, nourish the deceased in heaven or determine an auspicious day. They may be worshipped directly or, in various ways, be required to mediate communication between their devotees, their dead ancestors and Allah.

Such intermediaries between man and God are the target of reform in many religious traditions. Those most opposed to saints in western Gujarat argue that men are fundamentally equal in their potentials, and anyone acting as an intermediary on the pretext of genealogy is an obstacle in the way of man's rightful relationship with Allah. 
There are many other positions that are less hostile and admit the legitimacy of saints under some conditions: namely, the nature of their qualifications, the types of services they provide, the kinds of prayer over which they preside and the kinds of relationships they claim between themselves and the dead (see Robinson 1983, Mills 1998, Simpson 2006; also see Parkin (2000) for the Swahili coast).

I have often been struck by the fact that most people claim that associating with saints in particular ways is wrong; these are matters on which everyone seems to have an opinion. I am also struck by how small the number of people I know who have nothing whatsoever to do with the saints. The role of saints is a matter on which there is no conventional consensus, because there is both broad condemnation of particular practices and patronage of others. Given the uncertainties and fragilities of the self, and the unassailable idea of God, it is unsurprising that Muslims in Kachchh debate the correct relation between the two and, indeed, between Dasein (a vision the saints arguably embody) and the fleeting nature of individual human life. There are, however, two more sociological points here.

First, condemnation of saints comes in pretty standard forms and, as I have implied, is often a matter of minute differences in detail from the actual practices of the condemner. In a sense, narratives of reform have become a common property and as such occupy a peculiar status in sociological terms. They have strong intellectual and cultural histories, and are often reiterated in particular places (mosques and other religious functions), in certain ways by particular kinds of influential people (prayer leaders and so forth). They are essentially ritualized grand narratives, cultivated and honed and written down over the years. The more common narratives-on the status of the Prophet's birthday, on the importance of regular prayer, the ambiguous nature of intermediaries between man and Allah-are known in various forms to a great many Muslims, and in western India many of these narratives are also known by nonMuslims. Therefore, considerable analytical caution is necessary when juxtaposing narrative and practice, as a way of measuring what people may or may not believe in.

Secondly, there is the important matter of delimiting the scope of a popular belief among Muslims. Elsewhere, I have argued that a popular belief among Muslims in western India has at its core the principles of historicized Sunni Islam, but that these are profoundly influenced (both positively and negatively) by local conditions and rival social and divine cosmologies (see Simpson (2006)). Here, I provide indicative examples of how Muslims may 'believe' in 'non-Muslim 
things'. ${ }^{6}$ On some occasions, Muslims consider the rituals of Hinduism to be efficacious, if somewhat dangerous. While no one has ever told me, 'I find Hindu rituals efficacious', it is worth remarking that Muslim friends will not enter Hindu temples or shrines, even if there are no witnesses. On the dockside, they treat the flotsam from Hindu water-side rituals with extreme trepidation-if not to say fear-and have developed counter rituals for disposal. For Muslims of southern Kachchh, a plethora of forces are at work in the world; the religious routines and practices (sunnah) given by Islam provide a method for avoiding negative and corrupting influences, leaving people free to lead good lives after the example of the Prophet. In this sense, in life, Islam is seen as having something of a salvationary potential against the feckless and immanent temptations of lesser forces (I am reluctant to say gods) and spirits. At another level, the practice of regular prayer and reading from the Quran is a routine which prevents individuals from improper speculation and wandering into the realms of lesser powers and demons. Therefore, being a client of a shrine which other Muslims regard as backwards and superstitious (and this, remember, will include most people) still leaves a very long way to fall if things take a turn for the worse.

There are undoubtedly some who live according to a clear vision of Islamic practice; yet, for many more, narratives of religious reform are primarily good to think with, to work through the contradictions and uncertainties of their own lives. Many people I know simply have not, nor perhaps ever will they, made up their minds in any absolute sense as to what they should do, say or think-let alone hold as infallibleother than the certainty of a formless and intangible deity; they have businesses to run, houses to build, enemies to brutalize and other dreams to fulfil.

With this background, I now turn to the changing perspectives of the three men.

\section{The Three Men}

My focus on individual men shifts from the conventional stress on aggregates of castes and ethnic groups (after Mines 1994). Rafiq,

${ }^{6}$ The phrase 'non-Muslim things' is undeniably clumsy and arguably misleading. I have however used it here for want of a better alternative to indicate to the reader that I mean deities and ritual ideas that are conventionally considered part of popular Hinduism. 
whose meeting with the man in green I discussed above, is the wealthiest and most influential of the three. Rasheed is the second, a sailor, who once worked for Rafiq in the mid-199os, although I am unaware of any relationship between them today. Abbedin is the third, a Saiyed, who has no connection whatsoever I am aware of with Rafiq; Abbedin's eldest brother once beat Rasheed when he was a child for some now forgotten act of rascality; Rasheed remembers this; Abbedin's brother does not. The three men are now all in their mid-thirties and all are relatively successful in their own terms. They belong to different endogamous groups, and although the boundaries of such groups coincide on occasion with religious activity (such as specific mosques or particular saints being favoured) I wish to ignore the effects of this here.

How I know things about society in Kachchh has been very much dictated by the structures of my relationships with people like Rafiq, Rasheed and Abbedin. This is largely true for all anthropological fieldwork, but for an intimate discussion of how people may or may not have changed their minds about certain issues over time this fact seems to hold particular relevance. I have been able to measure what these men do against what they say over time. Over the last 10 years, we have learned how to ask each other questions in new ways. All three men now have some idea about anthropology and what I do with the information I write up as fieldnotes. They have become adept at predicting when I will ask questions and what form they will take. In some ways, they have learned to think about their society in terms of anthropology - although I doubt they see worth in this.

Let me now briefly describe how I know these men-not out of particularly introspective compulsions, but as a way of being clear about the status and limitations of my data. I got to know these three men in quite different ways; they also integrated me into their lives quite differently, and this affects how and what I know about them. I got to know Rafiq in a slow, gradual and accumulative way, but my relationship was always primarily with him and not with his family or domestic affairs. I got to know Rasheed through short periods of intense contact and long absences when he was working overseas; he rapidly integrated me into the routines of his family and domestic life both in Kachchh and Mumbai. I got to know Abbedin through a long period of intense contact, a few years of little contact and now regular contact both in India and England; I know very little about his family.

I have known Rafiq since the third day of my first period of fieldwork in the mid-199os. In the intervening years, I might even venture to 
say we have become friends. This has been slow, because he was very sceptical about my motives at first, and I was very much perturbed by his occasional threats of violence when he felt my questions too demanding. I spent nearly a year working in, or close to, his shipyards and talked to him for hours nearly every day. During this time, I got to know his father, brothers, sons and many of his male cousins. He allowed me to accompany him on business to timber yards in the east of Kachchh and on trips to his lawyer's office in Bhuj, the local administrative headquarters. I had known him for a year before he invited me into his house, which was right next to the shipyard where we both passed our days. He invited me for a meal at a restaurant after I had known him for about five years. We also met socially in Mumbai twice in the same year. In the seventh year after our initial encounter, he introduced me to his mother in the shadowy cool of the courtyard at the centre of his enormous house, which he shared with an extended family. The following year, my wife and father-in-law were invited for tea and biscuits. In all of these years, I never met Rafiq's wife; she lived secluded from strange men, and I was still counted as strange. Then, between my visits in 2004 and 2006, Rafiq's father died. He was an important local patriarch, and domineering within his household. In the family's house it was as if some great pressure had been released (there was grief too), and I was able to meet many of the women I had only heard about over the last decade as they moved around inside the house freely.

In the early years of our friendship, Rafiq appeared to me as a vociferous reformist, speaking out against practices he deemed corrupt, carefully choosing his own words and deeds, and investing heavily in outwards signs of his own piety. He always took care and time to explain things to me in formal language and would translate local terms of prayer and ritual into English, which he speaks very well. Looking back, part of this stage-managed appearance was of course about self-presentation, and to some degree Rafiq took on the task of being a representative of local Muslim orthodoxy for me. But he was also keen to teach me the vast array of swear words that are routinely used in the shipyards he owns and in whose work I was allowed to participate, albeit peripherally, as an anthropologist.

Like the majority of Muslims in Gujarat, in principle, Rafiq adheres to Hanafi law, but he is vague about what this entails. Like many Muslims in Kachchh (with the obvious exception of Shias), he prefers to call himself 'Sunni' or of the 'Sunnat Jamat' (i.e. Barevli). Rasheed and Abbedin do the same; by so doing, they deny the relevance of 
different doctrinal and legal frameworks within the general category of 'Sunni'. I have asked them many times about the influence of reformist and proselytizing organizations. They are aware of the work of such groups, but consistently reject all labels that are more specific than 'Sunni' for themselves.

At the time, and utterly independently of our relationship, Rafiq also had his own reasons for wanting to be associated with local conceptions of orthodoxy. He had been educated in a Christian boarding school far away from Kachchh and was keen to shed his association with Christianity, at least amongst Muslims. His family was involved in quite aggressive competitions over status and largesse in his village, and providing money for the construction of new mosques was one way of getting ahead in this struggle. Back then, there was a noticeable trend among many Muslims of all classes to distance themselves from practices associated in the popular imagination with Hinduism. Rafiq was well aware that his father and his father's friends had in the past been associated with some of the practices which many Muslims now spurned. He was most embarrassed and defensive about a video recording which showed his father being cured rather violently of a stomach disease by a man who claimed to control a large number of powerful jinn. Someone (I do not know who) had made copies of the video cassette, perhaps in an attempt to defame Rafiq, and for a short while it was available for rental in town. Rafiq seemed to think that his efforts at promoting new kinds of orthodoxy would compensate for some of his father's excesses, thereby securing his family's reputation.

If Rafiq initially appeared as one of the more observant Muslims on the quayside, more recently he has begun to appear as the most populist, if not to say irreverent. Again, he has his own reasons for changing stance as he begins to adopt the role of an informal political leader.

The infamous killing of many hundreds of Muslims in 2002 and the rise of a Hindu nationalist government in Gujarat has prompted some Muslims to search for bridges between their divided ranks. Occasionally, this might involve opposing the politics of Hindu nationalism, but mostly it is about reclaiming a sense of security from a hostile environment. In the late nineties-before natural disasters (a cyclone in 1997 and an earthquake in 2001) and the politics of Hindu nationalism loomed so large-aside from saint worship, it was the festival of Moharam that caused greatest controversy within the Muslim fold. Back then, most of my seafaring informants spoke out against it and stayed in their homes as processions took place 
through town. In 2004, a marked shift was apparent. Those previously dismissive of the festivities (I have both Rafiq and Rasheed on record stating quite clearly that it is a disrespectful sham) were now outside their houses offering sherbet drinks and words of encouragement to those carrying the shrines (tazias) of the martyrs through the streets; Rasheed even sponsored the construction of a small shrine. Many of the processions of a few years ago were confined to the streets of the town; today, all make the trip across the river and through neighbouring villages, symbolically linking the Muslim areas. People like Rafiq and Rasheed have put aside their previous attitudes towards the festival in order to foster a sense of unity through its practice.

I also have Rafiq on record saying extremely harsh things about particular families of local saints; he would curse publicly and extremely explicitly about them. For a while, in 1996, he also had a man working in one of his shipyards whose family claimed Saiyed status. The poor fellow was the butt of Rafiq's endless jokes about how the high and mighty had fallen to the level of a mere labourer; eventually, the man left the job because of the severity of the harassment.

In the mid-1990s, as previously mentioned, Rafiq's family was involved in a political struggle in its village. The rival faction was closely associated with a particular shrine. Rafiq had found it useful to discredit this shine, by suggesting that it was illegitimate and could play no role in the religion of the faithful. Recently, however, Rafiq has found it useful to befriend the saints he formerly denounced, donating money to their coffers as a way of gaining further influence outside his own immediate support network, perhaps as a way of manufacturing unity.

\section{Rasheed}

I first met Rasheed in 1997 at Bapu's teashop in an area of the town popular with sailors. Then, he wore heavy gold necklaces, pungent aftershave, branded t-shirts and replica jeans. He walked with a swagger and would laugh and joke confidently on the street, even with strangers. We began to meet regularly at Bapu's in the evenings. Rasheed introduced me to other sailors and together we talked of life at sea and in foreign ports. The sailors wore their wealth conspicuously and clearly enjoyed a strong sense of fraternity. For a novice anthropologist, Rasheed was a fantastic informant because he knew many people, while years of experience on international vessels 
had taught him that foreigners did not know the things he did, so he took it upon himself to explain such things.

He spent his early childhood with his parents and two brothers in a one-roomed house. This house was owned by a local shrine to which Rasheed's father paid a small amount of monthly rent in return for a property with no running water or power. The family had continued to pay for this house despite the fact Rasheed had recently purchased a grander three-bedroom property. Rasheed claimed the upstairs' front room as his own and decorated it with photographs he had taken of shopping malls and ships at anchor in Dubai, and prints of the famous Sufi shrine at Ajmer and various mosques and pilgrimage sites in Saudi Arabia. Over the years, Rasheed and I have become good friends. I have learned from him that people change their minds over time-a process we seldom notice in ourselves and perhaps only notice clearly in others if we keep notes.

During his seafaring career, first on a country craft owned by one of Rafiq's relatives and later on international tankers, Rasheed has slowly, but not imperceptibly, adopted new political and religious attitudes. This has brought him increasingly into conflict with his family. Change has been reflected in his more assiduous observation of prayers, in his clothes, his veneration of the words of the Quran, his deliberate attempt to learn more Arabic and his disavowal of what he considered to be public displays of false and immodest ritual during some festivals. These days, Rasheed no longer wears gold, considering it unsuitable. He has also abandoned counterfeit designer clothes and rests mostly content with simple cotton pyjamas. In the late 1990 , however, the most notable difference regarded the question of saints.

Rasheed's parents and brothers remained regular visitors to the shrine that owned their first house. Rasheed refused to visit this shrine or have any dealings with its saints because he felt they were not behaving like 'true' (his word) Muslims. As Rasheed's remittances had increased, however, his mother started to send daily parcels of food to the shrine. Constant tension between mother and son on this issue provoked many angry exchanges. She would accuse him of 'forgetting where he came from' and of 'ignoring those he owed'. Rasheed would counter by saying she was giving her (he perhaps really meant his) money to 'beggars', adding that it was wrong to think the saints were divine figures to 'whom she could never give enough'. Even then, the tension between Rasheed and his family was somewhat lopsided because his mother also respected Rasheed's 'new' religious ideas because they carried certain seals of authenticity. 
One of Rasheed's brothers was less careful in his criticism. In one of many loud arguments over Rasheed's attitudes, his brother said that Rasheed had simply replaced the 'cult of saints' with the 'cult of ship owners' and the 'cult of wealth', being utterly dependent on them, in a similar way, for success. The influential status of men like Rafiq (a status to which Rasheed aspired), he added, was rooted in money, not in the glorious history of Islam. Rasheed became apoplectic and his brother moved to rented accommodation a short time later. Although the brother was angry and possibly spite-ridden at Rasheed's successes, he had also perhaps pressed a raw nerve: whenever Rasheed was invited for prayer or a social function with ship owners, upon meeting those on whose ships he worked, he would stoop before them and touch his eyes and mouth against the hand they offered him, much as his non-seafaring brothers did when they called upon a saint.

Rasheed's story suggests a drift away from the saints, his opinions becoming entrenched with new wealth and the experience of life overseas; had we not met again after 1999, this might have been a fitting conclusion. The arguments he had with his mother about donating money and food were questioning the legitimacy of those saints who had patiently taught him the Quran when he was a boy. For Rasheed, I am sure his disquiet with the saints was not simply about contesting religion but also a way of rejecting the poverty of his youth (and, in a way, his family, particularly his father) and disassociating himself from the relatively low status of these particular saints as it was a way of contesting religious authority.

Rasheed's example illustrates that, for many Muslims, saint worship involves making choice, albeit the choice is always dictated by history and locality as well as whim, because there are simply so many shrines, even in small towns, that discrimination is necessary. People generally choose to build up regular and often inter-generational relationships with particular saints, rather than adopting a piecemeal approach. There are, of course, questions of status at stake here. Many prefer to ignore all local shrines and develop sympathies for national ones. Being far away, relationships with these shrines have more flexibility because the relationship is largely imagined. While distancing himself from his family's lowly saints, Rasheed has started to speak highly of the Ajmer Sheriff (the tomb of the Sufi Saint Khwaja Moinuddin Chisti in Rajasthan) and, although he has never visited, he keeps a small picture of the shrine in his wallet.

In 1998 I also got caught in a long squabble over Rasheed's refusal to go with his parents to a notable shrine to seek blessings for the 
forthcoming sailing season. Rasheed yet again repeated that visiting saints was wrong; he needed no intermediary to pray to Allah; in Islam all men were equal; although saints were of noble birth, there was nothing intrinsically special about them. On this occasion, Rasheed's family departed without him, leaving him alone in the house and free to invite his secret lover over for the afternoon. In subsequent years, Rasheed has conspicuously taken his family to that shrine before departing overseas. I can only think that in 1998 he used his wellrehearsed arguments about the illegitimacy of saints as an excuse for not going on the pilgrimage, enabling him to pursue his other, more worldly, interests.

This is not the end of the story. When I met Rasheed in 2003, he told me bluntly and with no hint of irony that the reformist Muslims of the Tablighi Jamat and the Ahl-e-Hadis had suffered the highest mortality rates in the devastating earthquake of 2001 . He was utterly convinced that this was because they had forsaken the traditions of protection offered by local saints and their shrines. For Rasheed, like many other Muslims in southern Kachchh, the terrible destruction of the earthquake has brought about a resurgence in the popularity of the saints. This again probably has as much to do with the political shifts that have taken place in Gujarat recently as it does with the natural disaster, as people search for idioms of unity rather than division.

\section{Abbedin}

At about the same time as I met Rafiq and Rasheed I also became acquainted with Abbedin, a Saiyed, whose family have a reputation for saintism. Now, he lives with his unmarried sister and his brothers and their families in a compound which contains their houses, a modest mosque, gardens and the graves of many of their ancestors. Some of these graves are covered with stone structures; others are simpler concrete affairs exposed to the elements. Abbedin and I have spent hundreds of hours here talking about religion, our ambitions and life in general, usually meeting in the heat of the afternoon between the time when he led zuhr and asr prayers in the mosque. Over time, I gradually became accustomed to the public and private working rhythms of the shrine. A steady stream of visitors came to pay their respects to Abbedin and his dead ancestors, some everyday. Visitors, even those much older than Abbedin, treated him with tremendous respect, bowing down to touch their eyes and mouth to his hand 
when approaching him. They addressed him formerly and would stand silently before him waiting until he granted permission to speak.

It had not always been like this. When I first met Abbedin, his father was still living and presided over the shrine with unquestioned authority. He had a prodigious reputation and people came from miles around to spend time in his shadow. He would hold court in a small yard at the entrance to the shrine everyday. He died rather suddenly and was buried in the shrine complex. The popularity he had enjoyed in life dwindled somewhat immediately after his death. Custodianship passed to Abbedin's eldest brother, who had a healthy knowledge of the Quran and of jurisprudence if not exactly the charismatic authority of his father. However, not long after taking over, he suffered head injuries in a freak accident. At the time, Abbedin was studying for an undergraduate degree in commerce from a local college and had other plans for his future. But happenstance got the better of him and he ended up leaving his studies to manage the shrine and its estate. He tentatively took on the role of advising visitors on moral and legal matters, just as his father had done and began to preside over prayers in the mosque and before the ancestral graves. Coconuts would be broken, incense lit and small charms left scattered upon the graves. Abbedin learned quickly to perform with authority and decorum and to provide clear answers to supplicant's concerns and anxieties. The shrine's routines became his routines: he ate, rested and offered counsel in its shadows.

In our meandering conversations, Abbedin told me what he knew of the history of the shrine and some of the major miracles that had been performed in its precincts. He told me of the protection it offered the townsfolk against malicious influences and how its power held evil ghosts and spirits at bay. He told me, somewhat sketchily, about his kin relations with other saints who presided over well-known shrines throughout India, who claimed descent from the Abdul Kadir Jilani, a twelfth century preacher of Baghdad. He told me how Saiyeds were the highest order in Muslim society, by virtue of descent and their propensity for wisdom, scholarship and discerning judgement; how they should be respected and worshipped by normal Muslims and how they had the capacity to act as a conduit between human desire and the world of non-human powers which could satisfy those desires.

Perhaps because he was unable to continue the tradition of miracles for which his father had been known, the number of visitors to the shrine declined. Gradually, however things in the shrine began to change. The prayer area before the mosque was enlarged, signs 
advising visitors how to behave appeared with Arabic words written in Gujarati script. Graves were repainted and cleared of graffiti, the brilliant green covers removed to reveal bare stone and concrete. Piles of incense stubs and the spent shells of coconuts disappeared. I never saw either in the shrine complex again, other than during the occasion of the shrine's annual festival. These actions were as much to align practices in the shrine with the prevailing orthodoxies of the time as they were out of Abbedin's own sense that he could not emulate his father's successes. As the number of regular visitors continued to fall, Abbedin turned to the shrine's estate for revenue to sustain his family. He carved kiosks into the outer walls of the shrine that opened out onto a busy commercial street and rented them to petty traders; for a while, one of them somewhat improbably became an amusement arcade.

Many of Abbedin's actions were doubly motivated: by a sense of duty to the memory of his father and the failing fortunes of his family. He clearly found running the shrine very stressful: he lost weight and his hair started to fall out. He had to cut public ties with friends and girlfriends from his college days because these relationships were unthinkable for a shrine custodian (later, when mobile phones were introduced, he found ways of communicating with some of these old friends). In order to cultivate his reputation, he stayed within the confines of the shrine day and night, to avoid the gossip and impurities of the street. As months passed, the behaviour of Abbedin's eldest brother grew increasingly erratic as his head injury began to heal. He announced plans for Abbedin's marriage to a cousin from Hyderabad. After the ensuing weeks of argument, Abbedin ran away to Dubai to work as an accountant; it later transpired that Abbedin had been plotting his escape for sometime. International migration was a release from both a marriage he did not want and the shrine. He lasted only weeks in Dubai before returning home. According to Abbedin, it was too hot in Emirates, and his pay too low for his skills. I also suspect that his return was because he was required to work hard for people who treated him with little respect, not recognizing his Saiyed status.

Later, Abbedin was employed by an educational trust with close ties to England. He started to make annual visits during Ramadan to raise money for the trust from Muslims in the East of England. His contacts were mostly third or fourth generation migrants from Gujarat who had historical associations with his shrine. He has found politics among Muslims in England to be noticeably more factionalized 
than in Gujarat, and he is not always welcome as a saintly Saiyed in people's houses. I have accompanied him on these forays and he hands out blessings and charms with greater enthusiasm than in Gujarat. His followers present him with money and he returns to India with cases bulging with clothes and gadgets. Over the years, I have seen Abbedin learn how to behave as a holy man and I have therefore always been slightly sceptical of his convictions. He was forced into the role by circumstance and his charisma often appears to be demand-led rather than supply driven.

In some memorably candid moments he has told me that Saiyeds do not have special powers, and, in a sense, it seems if he were not a Saiyed with responsibilities that hinged upon the fact he was he would have been more inclined towards practicing Islam in which saints had no place, perhaps more so than both Rafiq and Rasheed. To some extent, this is seen in the changes he has overseen in the shrine, with grave rituals simplified and the role of the mosque given a greater prominence, its signage Arabized. In the shrine, and whilst on tour in England, he is unshaven and wears simple and often grubby robes. In London, away from clutches of Gujarati Muslims, he dresses and behaves quite differently. Last year, he wanted to go to a pub and visit Madame Tussauds to have his photograph taken with a wax model of Kylie Minogue. I do not think he wanted to do these things simply because he thought I would like them, but equally I was not utterly convinced that this was not simply another kind of performance, another deliberate act of the many his life has become.

Abbedin inhabits an exceedingly broad range of geographical and cultural spaces. I have mentioned his forays to England where he spends time with people who have very firm ideas about the political potential of Islam. Meanwhile, in Kachchh, he has befriended a group of expatriate Europeans, whose numbers include a contemporary dancer, a conceptual artist and an educational psychologist who is also the founder of a well-known Oxford dinner club. Together, they make regular jokes at Abbedin's expense (in his presence) about pork and circumcision and generally talk as if Islam was superstitious nonsense; Abbedin responds in every conceivable way other than protest. Between the fervent 'fundamentalism' of Leicester and the 'avant-garde' conversation of his other friends in Kachchh, he returns home to a quiet and dignified life in the shrine. I see no difference in his level of investment or quest for recognition within all three situations. 


\section{Gujarat, Politics and Being Muslim}

After religious violence in Gujarat during 2002, and one key election later, many of my Muslim friends and informants are angry and disillusioned with party politics and the Hindu nationalist party in power. Many have undertaken additional building works on their properties, strengthening walls and gates and digging underground tunnels. As I stood with Rafiq on top of the walls he was constructing in front of his house to prevent 'intruders' gaining access from the river estuary, he told me that the government had gone too far; they were just creating problems for themselves by denying 'human rights' to Muslims. He said 'when Modi [the Chief Minister of Gujarat] talks of actions and reactions he does not seem to realize that we too may have to react. Do they just think we will lie down while they burn our homes and force us out?'

Rafiq has become increasingly politicized, speaking with a new vocabulary against the injustices of democracy and the way the state interprets the constitution. Along the coast, the spectres of violence and catastrophe have brought rival Muslim reformist organizations into dialogue with one another. Immediately after the earthquake of 2001, for example, all local Muslim factions (including Shias and the influential Lunar Committee) placed an advertisement in local newspapers stating Ahmediyas were not Muslims and people should not accept aid from them. More recently, Muslims have come together to protest about the unlawful killing of Saddam Hussein. Under these new circumstances, Rafiq and his friends are openly attempting to play a pivotal and paternalistic role by organizing unity through frequent meetings of different social and religious leaders, charity events and discussions with Muslims in neighbouring towns, to whom they were hostile in the very recent past.

In this paper, I have presented some of what I know about three men and their relationship to the question of saint worship in Gujarat over a 10 year period. I have framed snippets of their biographies within the context of how I know them as well as in the terms of their class position, their immediate family concerns and within the broader terrain of state-wide politics. Some of this material suggest an erosion of the authority of the saints and the social order over which they preside as scepticism, and convenience seems to increasingly characterize the practices surrounding them. Other aspects of the material suggest that the popularity of the saints is on the rise, as they become figureheads of protection and unity. 
Clearly, in the short-ethnographic term of a decade, it is impossible to claim that the demise of the saints is inevitable as natural disasters, the machinations of party politics, and personal circumstances have been shown to create flux and reflux in their popularity. I wish to stress however that while their fluctuating patterns of popularity are clearly related to shifts in the broader political climate, an individual's motivation for supporting saints in any particular context might be quite different: protection for Rasheed, unity for Rafiq and subsistence in Abbedin's case. But perhaps the more interesting point here is not simply whether there is a rise or fall in their popularity because popularity is clearly not a zero-sum game, but to what end their popularity is put.

I wish to conclude by drawing four further points out of this material. First, and most obviously, how these men behave in relation to ideas of Islam and reformism is largely context dependent and their actions and words are influenced by who they are with and the webs of power and influence that come to the fore in particular situations. Second, and beyond the first somewhat commonplace observation, it is also quite apparent that in and of themselves these men are not consistent in their words and deeds. By this I do not simply mean that they perform differently over time in relation to saints, although it is important that they do, but that they speak and act with different registers of truth and belief on different occasions. For example, they create other kinds of truth with lies, but in the instances I have discussed the plausibility and success of the lie (and other similar forms of playful manipulation) are given by the substantive provisions of the commonly known history and philosophy of Islam and social ideas of respect and decorum. Rafiq did not say, for example, to the man in green 'you should respect me because I have a big house'; rather, he told him that he had been on haj and was therefore worthy of respect. Similarly, Rasheed used reform as a water-tight alibi so that he could spend time with his lover.

That there are varying registers of truth in operation quite fundamentally exposes the limits of statements such as 'The Barelvis hold that spiritual intermediaries are a vital part of the society of Islam'. Through other lenses, the three men could be considered Barelvis, as most of the local scholars who speak in their mosques were trained in Barelvi madhrasas and pass on their own interpretations of Barelvi teachings; yet, I emphasize again that this is not a term any of the three men ever use. It seems clear however that these men do hold 
that spiritual intermediaries are a vital part of the society of Islam, but not in any straightforward sense whatsoever.

Third, all three men use narratives of reform to argue outside the realm of religious debate. Narratives of religious reform are grand objects. As I have said, they are very well known and perhaps unique as sociological artefacts. They can have a life quite independent of the beliefs and practices of those reciting them, or they can form the basis of a code of exemplary conduct. Such narratives and the social compulsions they imply are used as a source of moral and, indeed, argumentative reasoning outside the realm of theological debate: Rafiq attempts to build a political constituency, Rasheed avoids the long road trip to a shrine so he can entertain his lover and Abbedin flounders with the expectations of others in ways apparently quite at odds with what he himself deems appropriate.

From this, it is tempting to conclude that the correspondence of patterns of reasoning across domains is because Muslims do not distinguish religious from social life. I not only think this would be a misleading conclusion, but also an irresponsible one in the Indian context because it resonates strongly with the anti-Muslim rhetoric of Hindu nationalism and some of the less attractive forms of Orientalism. Most of my friends and informants quite consciously distinguish between social and religious life and, as I have discussed, often use the latter to gain sway within the former. ${ }^{7}$ The fact that they can do so with the complicity (tacit or otherwise) of others suggests that the domains cannot be clearly separated but that a malleable fault line exists.

Finally, all three men are both 'saint worshippers' and 'non-saint worshippers' at different times. I would like to hold this observation up to another contradiction at the heart of the body of literature on Muslims in South Asia. Assuming the majority of Muslims in India are indigenous converts; on one hand, the process of conversion is held to have been 'incomplete' and, somewhat hesitant in their newfound faith, they also held on to the old beliefs, only gradually putting them aside as the generations passed (as in Robinson 1983, Roy 1983). On the other hand, conversion is seen as having been abrupt and absolute and as the generations passed the forces of popular Hinduism eroded the original integrity of the faith (suggested by Ahmad (1984)). The former position is clearly more plausible, given lessons contained

7 This may be because Muslims are a visible minority in Gujarat and adopt other kinds of appearances in their social, economic and political lives. 
within the comparative literature on patterns of religious conversion, but this does not utterly exclude the possibility of the second condition coming into play at certain junctures. Abbedin, of course, sees little sense in the way this debate is framed, because he claims Saiyed status and thus some sense of continuity over time. In the abstract, however, Rafiq and Rasheed agree with Robinson and Roy on this issue. In their view, unknown ancestors submitted to Islam but retained Hindu names and customs; later, they passed to a syncretic phase before they embraced the correct-minded doctrines of today. In this light, however, they are to forever refine their faith and practice and move constantly towards an image of perfect practice. This is certainly how all three men feel in relation to (what they see as) their father's ad hoc religious ideas and practices-but as I have shown their own words and actions lead us to more hesitant conclusions.

The fact that Rafiq took the blessing before insulting the visiting saint suggests that caution is necessary in characterizing what facts about the world are salient to the belief and practice of Muslims. Shifts over time in what is thought of as correct Islam in western India can be a process of selection, of choosing from an array of forces and possibilities existing in the world many of which would not be recognized in relation to Muslims elsewhere. The tenor and targets of reformists in Gujarat are influenced heavily by the existence and pressures of other cosmologies, whether they are of a political, religious or economic nature, and cannot simply be seen as a purge along pre-determined lines-despite the rhetoric which I have suggested supplies the impression of such pre-determination. There are many levels of conceit in operation which influence what people do or say in relation to their equally contextual beliefs and practices other than the dogmas of institutionalized religious thought, and some of these influences are very intimate and mundane.

There is something somewhat mechanical if not to say functional about the idea that faith is gradually moving towards an image of perfection because it seems to assume religious values function independently of human action. When we focus on the vagaries and anxieties of individual lives, or on individual lives in relation to their fathers, the picture is far less clear-cut. The separate cases I have discussed here animate some of immediate issues to arise from the way Rafiq levelled insults at the man in green. Perhaps, had it have been another day, or if his attempt to get customs clearance for his vessel had not been foiled due to missing paperwork, and he was not in such a foul mood, he might have behaved differently. Indeed, 
had the men on the vessel against the quay that day not worked for one of the men with whom Rafiq's family was feuding then he might also have behaved quite differently, not taking the chance to impress the employees of his rival in his rival's absence. Recently, Rafiq has started to wear clothes and a beard in the style of his late father. $\mathrm{He}$ told me that in the past he had taken the behaviour of his father to be ignorant and he often felt ashamed. Now, faced with the burden of the responsibilities his father had carried, Rafiq is beginning to realize how utterly wise his father's populism was. It is of course too late for Rafiq to tell the dead man in person, so he has turned to a spiritual intermediary in the hope the message can be passed on.

\section{Bibliography}

Ahmad, I. (ed.) (1984) [originally published in 1981] Ritual and Religion among Muslims in India. (New Delhi: Manohar).

Asad, T. (1986) 'The idea of an anthropology of Islam', Occasional Papers. (Washington D.C.: Center for Contemporary Arab Studies).

Das, V. (1984) 'For a folk-theology and theological anthropology of Islam', Contributions to Indian Sociology, 1 8(2): 292-300.

Eaton, R. M. (1978) Sufis of Bijapur Izoo- I 7oo: Social Roles of Sufis in Medieval India. (Princeton, NJ: Princeton University Press).

Eaton, R. M. (2001) [originally published in 2000] Essays on Islam and Indian History. (New Delhi: Oxford University Press).

Eickelman, D. F. (1981) The Middle East. An Anthropological Approach. (Englewood Cliffs, NJ: Prentice-Hall).

Eickelman, D. F. (1982) 'The study of Islam in local contexts', Contributions to Asian Studies, 17: 1-16.

Eickelman, D. F. and J. Piscatori, (1996) Muslim Politics. (Princeton, NJ: Princeton University Press).

Engineer, A. A. (1989) The Muslim Communities of Gujarat. An Exploratory Study of Bohras, Khojas and Memons. (Delhi: Ajanta Publications).

Ewing, K. (1997) Arguing Sainthood: Modernity, Psychoanalysis, and Islam. (Durham, NC: Duke University Press).

Gellner, E. (1969) Saints of the Atlas. (Chicago, IL: University of Chicago Press).

Gibb, H. A. R. (1972) [originally published in 1947] Modern Trends in Islam. (New York: Octagon Books).

Giddens, A. (1979) Central Problems in Social Theory. Action, Structure and Contradiction in Social Analysis. (London: The Macmillan Press).

Heidegger, M. (1962) Being and Time. (trans.J. Macquarrie and E. Robinson). (Oxford: Blackwell).

Holland, D. and K. Leander (eds.) (2004) 'Ethnographic studies of subjectivity and positioning: An introduction', ETHOS, 32(2): 127-139.

Lindholm, C. (1986) 'Caste in Islam and the problem of deviant systems: A critique of recent theory', Contributions to Indian Sociology, 20(1): 61-73.

Marsden, M. (2005) Living Islam: Muslim Religious Experience in Pakistan's North-West Frontier. (Cambridge: Cambridge University Press). 
Metcalf, B. D. (2004) Islamic Contestations. Essays on Muslims in India and Pakistan. (New Delhi: Oxford University Press).

Metcalf, B. D. (2005) [originally published in 1982] Islamic Revival in British India: Deoband, I860-1900. (New Delhi: Oxford University Press).

Mills, S. L. (1998) 'The hardware of sanctity: Anthropomorphic objects in Bangladeshi Sufism', in P. Werbner and H. Basu (eds.) Embodying Charisma. Modernity, Locality and the Performance of Emotion in Sufi Cults. (London: Routledge).

Mines, M. (1994) Public Faces, Private Lives. Community and Individuality in South India, (Berkeley, CA: University of California Press).

Misra, S. C. (1964) Muslim Communities in Gujarat. Preliminary Studies in their History and Social Organisation. (London: Asia Publishing House).

Parkin, D. (2000) 'Inside and outside the mosque: A master trope', in D. Parkin and S. C. Headley (eds.) Islamic Prayer Across the Indian Ocean. Inside and Outside the Mosque. (Richmond: Curzon).

Reetz, D. (2006) Islam in the Public Sphere. Religious Groups in India I9oo- 1947. (New Delhi: Oxford University Press).

Robinson, F. (1983) 'Islam and Muslim society in South Asia', Contributions to Indian Sociology, $17(2): 185^{-203}$.

Robinson, F. (2001) The Ulama of Farangi Mahall and Islamic Culture in South Asia. (London: Hurst and Company).

Robinson, F. (2003) [originally published in 2000] Islam and Muslim history in South Asia. (New Delhi: Oxford University Press).

Robinson, R. (2005) Tremors of Violence. Muslim Survivors of Ethnic Strife in Western India. (New Delhi: Sage Publications).

Rosen, L. (1984) Bargaining for Reality: The Construction of Social Relations in a Muslim Community. (Chicago, IL: Chicago University Press).

Roy, A. (1983) The Islamic Syncretistic Tradition in Bengal. (Princeton, NJ: Princeton University Press).

Simpson, E. (2006) Muslim Society and the Western Indian Ocean. The Seafarers of Kachchh. (London: Routledge).

Soares, B. J. (2005) Islam and the Prayer Economy. History and Authority in a Malian Town. (Edinburgh: Edinburgh University Press for the International African Institute).

Verkaaik, O. (2004) Migrants and Militants. Fun and Urban Violence in Pakistan. (Princeton, NJ: Princeton University Press).

Zaman, M. Q. (1999a) 'Commentaries, print and patronage: "Hadith" and the Madrasas in Modern South Asia', Bulletin of the School of Oriental and African Studies, University of London, 62(1): 6o-81.

Zaman, M. Q. (1999b) 'Religious education and the rhetoric of reform: The Madrasa in British India and Pakistan', Comparative Studies in Society and History, 41 (2): 294323 . 